\title{
APLIKASI PUPUK CAIR PLUS SILIKA DENGAN PUPUK ANORGANIK N, P, K TERHADAP PERTUMBUHAN DAN HASIL TANAMAN PADI (Oryza Sativa L) PADA TANAH INCEPTISOL JATINANGOR
}

\author{
Eso Solihin ${ }^{1}{ }^{*}$, Apong Sandrawati ${ }^{1}$, Wawan Kurniawan ${ }^{1}$, Haris Maulana ${ }^{1}$, Zaenal Mutaqin ${ }^{2}$ \\ ${ }^{1 *}$ Program studi Agroteknologi Fakultas Pertanian UNPAD \\ ${ }^{2}$ Politeknik Negeri Pontianak \\ eso.solihin@unpad.ac.id
}

\begin{abstract}
Abstrak
Percobaan ini bertujuan untuk mengetahui pengaruh berbagai konsentrasi pupuk cair plus silika yang dikombinasikan dengan pupuk anorganik $\mathrm{N}, \mathrm{P}$, dan $\mathrm{K}$ terhadap pertumbuhan dan hasil tanaman padi (oryza sativa L). Percobaan ini telah dilaksanakan pada bulan Juli 2018 sampai dengan November 2018 di kebun percobaan Ciparanje Fakultas Pertanian Universitas Padjadjaran, Jatinangor, Sumedang. Metode yang digunakan adalah Rancangan Acak Kelompok (RAK) yang terdiri dari sepuluh perlakuan dengan tiga kali ulangan; Perlakuan (A) Kontrol, (B) NPK standar, (C) Pupuk Cair Plus Silika, (D) 1/4 NPK + Pupuk Cair Plus Silika, (E) 1/2 NPK + Pupuk Cair Plus Silika, (F) 3/4 NPK + Pupuk Cair Plus Silika, (G) NPK + Pupuk Cair Plus Silika, (H) 3/4 NPK + 1/4 Pupuk Cair Plus Silika, (I) 3/4 NPK + 1/2 Pupuk Cair Plus Silika, (J) $3 / 4$ NPK $+3 / 4$ Pupuk Cair Plus Silika. Hasil penelitian ini menunjukkan bahwa terdapat pengaruh pemberian pupuk silika terhadap pertumbuhan dan jumlah anakan tanaman padi setelah tanaman padi 8 MST. Perlakuan F (3/4 NPK + Pupuk Cair Plus Silika) memberikan nilai tertinggi terhadap hasil tanaman padi dengan dengan hasil 53,31 gram pertanaman.
\end{abstract}

Kata Kunci: Inceptisol, Padi, Pemupukan, Produktivitas, Silika

\section{Abstract}

This experiment aims to determine the effect of various concentrations of liquid fertilizer plus silica combined with $N, P$, and $K$ inorganic fertilizers on the growth and yield of rice plants (oryza zativa). The trial was conducted in July 2018 to November 2018 in the Ciparanje experimental garden of the Faculty of Agriculture, Padjadjaran University, Jatinangor, Sumedang. The method used is Randomized Block Design (RBD) which consists of ten treatments with three replications; Treatment (A) Control, (B) standard NPK, (C) Plus Silica Liquid Fertilizer, (D) 1/4 NPK + Silica Plus Liquid Fertilizer, (E) $1 / 2 N P K+$ Silica Plus Liquid Fertilizer, $(F)$ 3/4 NPK + Liquid Fertilizer Silica Plus, (G) NPK + Silica Plus Liquid Fertilizer, (H) 3/4 $N P K+1 / 4$ Silica Plus Liquid Fertilizer, (I) $3 / 4 N P K+1 / 2$ Silica Plus Liquid Fertilizer, (J) 3/4 NPK + 3/4 Silica Plus Liquid Fertilizer. The results showed that there was an effect of silica fertilizer on the growth and number of tillers after rice $8 \mathrm{MST}$. The treatment of $F$ $(3 / 4$ NPK + Liquid Fertilizer Plus Silica) gave the highest value to the yield of rice plants with the results of 53.31 grams of crop.

Keywords: Fertilizer, Inceptisols, Productivity, Rice, Silica

\section{Pendahuluan}

Indonesia merupakan salah satu negara dengan konsumsi makanan pokok berupa beras terbanyak didunia. Jumlah konsumsi beras tahun 2019 adalah 94,9 kg per kapita (BPS, 2020). Konsumsi beras di Indonesia setiap tahuannya terus meningkat seiring dengan pertumbuhan penduduk, maka sangat penting untuk meningkatkan produksi padi nasional. Peningkatan produksi padi dapat dicapai melalui peningkatan indeks panen dan peningkatan produksi tanaman setiap musim tanam (Santoso, 2014). Peningkatan produksi harus diiringi dengan peningkatan produktivitas melalui penerapan teknik budidaya yang tepat seperti penggunaan benih bermutu, pengolahan tanah, dan pemupukan.

Peningkatan produksi dapat pula melalui ekstensifikasi pertanianian dengan cara perluasan lahan pertanian namun lahan-lahan untuk peningkatan produksi pertanian tidak semuanya subur. Salah satu lahan pertanian yang kurang subur dan dijadikan lahan pertanian adalah lahan sawah dengan ordo tanah inceptisol. Sebaran tanah inceptisol di Indonesia cukup 
luas sekitar 99,50 juta ha atau sekitar 52,89\% dari luas daratannya (BBSDLP, 2020). Kendala yang dihadapi pada pengolahan tanah inceptisol salah satunya adalah sifat kimia dari tanah tersebut yang memiliki kandungan hara rendah. Maka untuk meningkatkan kesuburan tanah tersebut diperlukan masukan berupa pupuk yang seimbang.

Menurut Irianto (2010), lahan sudah sakit atau kandungan haranya rendah, perlu diberikan pupuk agar dapat menyuburkan tanah kembali. Pemupukan merupakan cara pemberian hara pada tanaman agar memenuhi kebutuhan nutrisinya supaya proses fisiologi yang terjadi pada tanaman berjalan dengan baik dan meningkatkan hasil produksi tanaman baik kualitasnya maupun kuantitasnya (Isnawan, 2015). Pemberian pupuk pada tanaman dapat berupa pupuk organik dan anorganik baik itu berbentuk cair atau padat. Unsur hara dalam tanah akan bertambah dengan pemberian pupuk, Unsur hara yang mutlak diperlukan oleh tanaman adalah nitrogen, fosfor dan kalium. Selain ketiga unsur hara tersebut, unsur Silika (Si) diperlukan dalam jumlah besar oleh tanaman padi (Amrulloh dkk, 2014). Pada tanaman padi kebutuhan Si lebih banyak daripada unsur hara makro N, P dan K. Setiap 5 ton ha ${ }^{1}$ hasil padi, terangkut sebanyak $230-470 \mathrm{~kg}$ Si ha-1 oleh tanaman, sedangkan $\mathrm{N}, \mathrm{P}$ dan $\mathrm{K}$ yang terangkut berkisar 75-120 kg N ha ${ }^{-1}, 20-25 \mathrm{~kg}$ P ha-1 dan 23-257 $\mathrm{kg} \mathrm{K} \mathrm{ha}^{-1}$ (Casman et al, 1997).

Hasil limbah pertanian tanaman padi berupa sekam dan jerami dapat dijadikan sumber Si ke dalam tanah. Unsur silika dalam sekam dapat diberikan secara utuh, bentuk arang atau abu. Sekam padi yang dibakar menghasilkan abu sekam dengan kandungan $\mathrm{SIO}_{2}$ tinggi. Menurut Ginanjar, dkk (2014), proses pembakaran sekam menghasilkan 20\% abu dengan kandungan unsur SI sekitar 86-97\%. Pemberian pupuk Si yang berasal dari abu sekam padi dapat dilakukan dengan mencampurkannya ke dalam pupuk cair yang juga diiringi dengan pemupukan $\mathrm{N}, \mathrm{P}$ dan $\mathrm{K}$ secara berimbang. Penelitian ini bertujuan untuk mengetahui pengaruh berbagai konsentrasi pupuk cair plus silika yang dikombinasikan dengan pupuk anorganik N, P, dan $\mathrm{K}$ terhadap pertumbuhan dan hasil tanaman padi.

\section{Bahan dan Metode}

Penelitian ini dilaksanakan di Rumah Kaca Fakultas Pertanian Universitas Padjadjaran Kecamatan Jatinangor Kabupaten Sumedang pada bulan Juli 2018 sampai dengan bulan November 2018. Dengan bahanbahan yang digunakan adalah benih padi varietas Ciherang, pupuk cair organik yang ditambahkan abu sekam padi dengan kehalusan 200 mesh dan kadar $\mathrm{SiO}_{2}$ $87 \%$, pupuk anorganik urea, SP-36, KCl. Sedangkan alat yang digunakan adalah ember, cangkul, sprayer digunakan untuk menyemprot pupuk cair, meteran/penggaris untuk mengamati tinggi tanaman, timbangan, dan alat tulis. Percobaan dalam penelitian ini menggunakan Rancangan Acak Kelompok (RAK), Sepuluh perlakuan dan tiga ulangan.

Perlakuan (A) Kontrol, (B) NPK standar, (C) Pupuk Cair Plus Silika, (D) 1/4 NPK + Pupuk Cair Plus Silika, (E) $1 / 2$ NPK + Pupuk Cair Plus Silika, (F) 3/4 NPK + Pupuk Cair Plus Silika, (G) NPK + Pupuk Cair Plus Silika, (H) 3/4 NPK + 1/4 Pupuk Cair Plus Silika, (I) 3/4 NPK + 1/2 Pupuk Cair Plus Silika, (J) 3/4 NPK + 3/4 Pupuk Cair Plus Silika. Pada percobaan ini, menggunakan ember dengan ukuran $25 \times 30 \mathrm{~cm}$ dan terdapat dua unit percobaan yaitu: satu unit digunakan untuk pengamatan pada fase vegetatif maksimum dan satu unit lagi untuk pengamatan sampai fase generatif akhir. Jumlah ember masing-masing unit adalah $10 \times 3=$ 30 ember, sehingga untuk keseluruhan percobaan terdapat 60 ember.

Pada penelitian ini pengamatan yang diamati adalah Tinggi Tanaman, Jumlah Anakan dan Bobot Gabah Kering Panen (GKP). Data hasil pengamatan dianalisis dengan sidik ragam pada tingkat kepercayaan $95 \%$. Untuk mengetahui perbedaan diantara perlakuan dengan Uji Jarak Ganda Duncan (DMRT) pada tingkat kepercayaan $95 \%$.

Tanah yang digunakan adalah tanah Inceptisols dari lahan kebun percobaan Fakultas Pertanian UNPAD yang berada di Desa Cileles Kecamatan Jatinangor Kabupaten Sumedang. Tanah diambil pada kedalaman 0-20 cm, kemudian dimasukan kedalam ember setelah itu dilumpurkan dengan cara ditambahkan air sampai ketinggian $3 \mathrm{~cm}$. kondisi air selulu dipertahankan setinggi $3 \mathrm{~cm}$ sampai masa vegetatif akhir dengan cara melakukan penyiraman yang dilakukan setiap pagi atau sore hari.

Pengamatan Tinggi Tanaman dan Jumlah Anakan dilakukan pada waktu 2, 4, 6 dan 8 Minggu Setelah Tanam (MST), sementara pengamatan Bobot Gabah Kering Panen dilakukan pada waktu generatif akhir (pada umur 110 hari), bila gabah pada malai menguning mencapai $90 \%$, butir gabah mengeras dan tangkai malai merunduk. Panen dilakukan dengan memotong malai menggunakan sabit. kemudian dirontokan untuk memisahkan gabah dari malainya. Gabah Kering Panen kemudian ditimbang.

\section{Hasil dan Pembahasan}

Tinggi Tanaman

Tinggi tanaman merupakan salah satu parameter pertumbuhan yang sering diukur dalam 
melihat faktor pertumbuhan tanaman, hal ini didasarkan kenyataan bahwa tinggi tanaman merupakan ukuran pertumbuhan yang paling mudah dilihat (Sitompul dan Guritno, 1995). Tinggi tanaman berkaitanpula dengan faktor dan komponen tumbuh lainnya, seperti lingkungan yang menekan atau mendorong pertumbuhan, serta jumlah daun, panjang daun, perakaran serta anakan yang akan berkembang. Karena itu tinggi sesuai dengan sifat genetiknya sangat

Tabel 1. Pengaruh pemeberian pupuk cair dan pupuk anorganik N, P, K terhadap tinggi tanaman padi

\begin{tabular}{|c|c|c|c|c|}
\hline \multirow{2}{*}{ Perlakuan } & $2 \mathrm{MST}$ & $4 \mathrm{MST}$ & $6 \mathrm{MST}$ & $8 \mathrm{MST}$ \\
\hline & \multicolumn{4}{|c|}{-------------------------------- cm ---------------------------------- } \\
\hline $\mathrm{A}(0 \mathrm{PCS}+0 \mathrm{NPK})$ & $26,70 \mathrm{a}$ & $41,33 \mathrm{a}$ & $54,67 \mathrm{a}$ & $56,00 \mathrm{a}$ \\
\hline B ( 0 PCS + 1 NPK) & $31,17 \mathrm{a}$ & $43,53 \mathrm{a}$ & $56,83 \mathrm{a}$ & $57,03 \mathrm{ab}$ \\
\hline $\mathrm{C}(1 \mathrm{PCS}+0 \mathrm{NPK})$ & $30,53 \mathrm{a}$ & 43,17 a & $55,75 \mathrm{a}$ & $62,17 \mathrm{c}$ \\
\hline $\mathrm{D}(\mathrm{PCS}+1 / 4 \mathrm{NPK})$ & $29,73 \mathrm{a}$ & $43,63 \mathrm{a}$ & $57,10 \mathrm{a}$ & $62,40 \mathrm{c}$ \\
\hline $\mathrm{E}(1 \mathrm{PCS}+1 / 2 \mathrm{NPK})$ & $32,07 \mathrm{a}$ & $44,50 \mathrm{a}$ & $57,47 \mathrm{a}$ & $63,50 \mathrm{c}$ \\
\hline $\mathrm{F}(1 \mathrm{PCS}+3 / 4 \mathrm{NPK})$ & $31,00 \mathrm{a}$ & $44,53 \mathrm{a}$ & $57,67 \mathrm{a}$ & $64,20 \mathrm{c}$ \\
\hline G ( 1 PCS + 1 NPK ) & $30,60 \mathrm{a}$ & $44,50 \mathrm{a}$ & 57,17 a & $64,03 \mathrm{c}$ \\
\hline $\mathrm{H}(1 / 4 \mathrm{PCS}+3 / 4 \mathrm{NKP})$ & $30,23 \mathrm{a}$ & $43,40 \mathrm{a}$ & $56,83 \mathrm{a}$ & $59,50 \mathrm{abc}$ \\
\hline I ( $1 / 2 \mathrm{PCS}+3 / 4 \mathrm{NPK})$ & $30,17 \mathrm{a}$ & $44,03 \mathrm{a}$ & $57,17 \mathrm{a}$ & $61,30 \mathrm{bc}$ \\
\hline $\mathrm{J}(3 / 4 \mathrm{PCS}+3 / 4 \mathrm{NPK})$ & $30,97 \mathrm{a}$ & $45,83 \mathrm{a}$ & $57,83 \mathrm{a}$ & $64,00 \mathrm{c}$ \\
\hline
\end{tabular}

Keterangan: Angka rerata yang diikuti huruf yang sama tidak berbeda nyata berdasarkan Uji Jarak Berganda Duncan pada Taraf $5 \%$

Hasil pengujian tersebut menunjukan tida ada perbedaan yang nyata antar perlakuan dengan kontrol pada 2 MST, 4 MST dan 6 MST sementara pada 8 MST menunjukan perbedaan yang nyata antara perlakuan dibandingkan dengan kontrol. Pada perlakuan 2 MST perlakuan A (kontrol) menunjukan tinggi yang lebih rendah dibandingkan perlakuan lainnya dengan tinggi tanaman $26,70 \mathrm{~cm}$, hal serupa juga terjadi pada 4 MST, 6 MST dan 8 MST dengan tinggi tanaman $41,33 \mathrm{~cm}, 54,67 \mathrm{~cm}$ dan $56,00 \mathrm{~cm}$. Sementara perlakuan dengan tinggi tanaman padi paling tinggi pada 2 MST ditunjukan pada perlakuan B dengan tinggi $31,17 \mathrm{~cm}$, sementara pada 4 MST dan 6 MST perlakuan paling tinggi terlihat pada perlakuan $\mathbf{J}$ dengan tinggi $45,83 \mathrm{~cm}$ dan $57,83 \mathrm{~cm}$, sedangkan pada 8 MST perlakuan yang paling tinggi ditunjukan oleh perlakuan $\mathrm{F}$ dengan $64,20 \mathrm{~cm}$. hal ini dikarenakan pada tanaman dengan usia 2 MST, 4 MST dan 6 MST tanaman belum menyerap unsur hara yang diberikan secara optimal sehingga perbedaannya masih belum terlihat. Sementara pada 8 MST ketersediaan hara makro maupun mikro dari pupuk yang diberikan semakin meningkat, sehingga meningkat pula penyerapan hara oleh akar yang kemudian ditranslokasikan ke batang dan daun (Rosmarkam dan Yuwono, 2002).

Menurut Sugiyanta (2007), meningkatnya tinggi tanaman padi dipengaruhi oleh unsur makro relevan dengan produktivitas hasil tanaman itu serta lingkungan tumbuh yang mempengaruhinya. Tanaman yang tinggi akan berpengaruh saling menaungi di antara susunan daun yang tumbuh dan belum tentu akan menghasilkan gabah berisi secara maksimum.

Data hasil analisis ragam pengaruh penggunaan pupuk cair plus silika dan pupuk anorganik $\mathrm{N}, \mathrm{P}, \mathrm{K}$ terhadap tinggi tanaman padi disajikan pada Tabel 1. 
yang nyata dibandingkan dengan kontrol. Pada 2 MST jumlah anakan tertinggi ditunjukan oleh perlakuan $\mathrm{E}$ dengan jumlah 4,6, dan diikuti oleh perlakuan $\mathrm{G}, \mathrm{H}$, dan I dengan jumlah 4,33 sementara perlakuan terendah diperlihatkan oleh perlakuan $\mathrm{A}$ dan $\mathrm{F}$ dengan jumlah 3,67 .

Tabel 2. Pengaruh pemeberian pupuk cair dan pupuk anorganik N, P, K terhadap jumlah anakan tanaman padi.

\begin{tabular}{|c|c|c|c|c|}
\hline \multirow{2}{*}{ Perlakuan } & $2 \mathrm{MST}$ & $4 \mathrm{MST}$ & $6 \mathrm{MST}$ & $8 \mathrm{MST}$ \\
\hline & \multicolumn{4}{|c|}{-----------------------------Batang------------------------------- } \\
\hline $\mathrm{A}(0 \mathrm{PCS}+0 \mathrm{NPK})$ & $3,67 \mathrm{a}$ & $9,00 \mathrm{a}$ & $26,67 \mathrm{a}$ & $29,67 \mathrm{a}$ \\
\hline $\mathrm{B}(0 \mathrm{PCS}+1 \mathrm{NPK})$ & $4,00 \mathrm{a}$ & $11,67 \mathrm{a}$ & $28,00 \mathrm{a}$ & $49,00 \mathrm{~b}$ \\
\hline $\mathrm{C}(1 \mathrm{PCS}+0 \mathrm{NPK})$ & $4,00 \mathrm{a}$ & $9,67 \mathrm{a}$ & 28,67 a & $64,67 \mathrm{c}$ \\
\hline $\mathrm{D}(1 \mathrm{PCS}+1 / 4 \mathrm{NPK})$ & 3,67 a & $10,00 \mathrm{a}$ & 28,67 a & $65,33 \mathrm{c}$ \\
\hline $\mathrm{E}(1 \mathrm{PCS}+1 / 2 \mathrm{NPK})$ & $4,67 \mathrm{a}$ & $10,33 \mathrm{a}$ & $32,33 \mathrm{a}$ & $66,67 \mathrm{c}$ \\
\hline $\mathrm{F}(1 \mathrm{PCS}+3 / 4 \mathrm{NPK})$ & $3,67 \mathrm{a}$ & $10,67 \mathrm{a}$ & $32,67 \mathrm{a}$ & $68,67 \mathrm{c}$ \\
\hline G ( 1 PCS + 1 NPK $)$ & 4,33 a & 8,67 a & $31,00 \mathrm{a}$ & $66,00 \mathrm{c}$ \\
\hline $\mathrm{H}(1 / 4 \mathrm{PCS}+3 / 4 \mathrm{NKP})$ & 4,33 a & $10,67 \mathrm{a}$ & $32,33 \mathrm{a}$ & $64,67 \mathrm{c}$ \\
\hline I ( 1/2 PCS + 3/4 NPK ) & $4,33 \mathrm{a}$ & $11,00 \mathrm{a}$ & $33,67 \mathrm{a}$ & $67,33 \mathrm{c}$ \\
\hline $\mathrm{J}(\mathrm{3} / 4 \mathrm{PCS}+3 / 4 \mathrm{NPK})$ & $4,00 \mathrm{a}$ & $9,33 \mathrm{a}$ & $34,33 \mathrm{a}$ & $68,67 \mathrm{c}$ \\
\hline
\end{tabular}

Keterangan: Angka rerata yang diikuti huruf yang sama tidak berbeda nyata berdasarkan Uji Jarak Berganda Duncan pada Taraf $5 \%$.

Pada perlakuan 4 MST yang menunjukan perlakuan lebih tinggi ditunjukan oleh perlakuan B dengan jumlah anakan 11,67 diikuti oleh perlakuan I denagn 11 serta $\mathrm{H}$ dan $\mathrm{F}$ dengan julmah 10,67. Perlakuan terendah ditunjukan oleh perlakuan $\mathrm{G}$ dengan jumlah 8,67. Pada perlakuan 6 MST perlakuan tertinggi diperlihatkan oleh perlakuan $\mathbf{J}$ dengan jumlah anakan 34,33 dan perlakuan terendah terlihat pada perlakuan A yaitu 26,67.

Pada perlakuan 8 MST terlihat perbedaan yang nyata diperlihatkan pada perlakuan dengan pemberian Pupuk cair dibanding dengan kontrol dan pupuk anorganik dan yang memiliki jumlah anakan paling tinggi ditunjukan oleh perlakuan J dan F dengan jumlah anakan 68,67. Hal ini dikarenakan terjadi karena ketersediaan hara dalam tanah meningkat pada akhir masa vegetatif, sehingga jumlah hara dalam daun terutama klorofil akan meningkat. Peningkatan kandungan klorofil akan meningkatkan laju fotosintesis tanaman dan kandungan fotosintat yang dihasilkan sehingga akan meningkatkan pertumbuhan dan jumlah

Tabel 3. Pengaruh pemeberian pupuk cair dan pupuk anorganik N, P, K terhadap hasil tanaman padi anakan. Menurut Hadisuwito (2007) menyatakan bahwa fungsi unsur hara makro seperti N, P, K dapat membentuk protein ,klorofil, sumber energi untuk membantu tanaman dalam perkembangan fase vegetatif, ,dan pembentukan karbohidrat serta fungsi hara mikro yang tersedia dan diserap oleh tanaman untuk pertumbuhan vegetatif tanaman.

\section{Bobot Gabah Kering Panen}

Hasil analisis ragam menunjukan tidak ada perbedaan yang nyata antara pemberian pupuk cair dan pupuk anorganik terhadap hasil tanaman padi antar perlakuan dengan kontrol. Pemberian pupuk anorganik dengan dosis 1 anjuran pada tanaman padi (perlakuan B) menujukan hasil 44,51 g bobot gabah kering panen pertanaman. Sedangkan pada perlakuan tanpa pupuk cair dan pupuk anorganik (perlakuan A) menunjukan hasil 38,58 g bobot gabah kering panen pertanaman yang merupakan hasil terendah.

\begin{tabular}{cc}
\hline Perlakuan & Gabah Kering Panen Pertanaman $(\mathrm{g})$ \\
\hline A $(0$ PCS $+0 \mathrm{NPK})$ & $38,58 \mathrm{a}$ \\
B $(0 \mathrm{PCS}+1 \mathrm{NPK})$ & $44,51 \mathrm{a}$ \\
C $(1 \mathrm{PCS}+0 \mathrm{NPK})$ & $41,65 \mathrm{a}$ \\
D $(1 \mathrm{PCS}+1 / 4 \mathrm{NPK})$ & $42,21 \mathrm{a}$
\end{tabular}




$\begin{array}{cc}\text { E ( } 1 \text { PCS + 1/2 NPK ) } & 44,55 \mathrm{a} \\ \text { F ( 1 PCS + 3/4 NPK ) } & 53,31 \mathrm{a} \\ \text { G ( } 1 \text { PCS + 1 NPK ) } & 45,40 \mathrm{a} \\ \text { H ( } 1 / 4 \text { PCS + 3/4 NKP ) } & 40,93 \mathrm{a} \\ \text { I ( } 1 / 2 \text { PCS + 3/4 NPK ) } & 43,29 \mathrm{a} \\ \text { J ( } 3 / 4 \text { PCS + 3/4 NPK ) } & 44,63 \mathrm{a}\end{array}$

Keterangan: Angka rerata yang diikuti huruf yang sama tidak berbeda nyata berdasarkan Uji Jarak Berganda Duncan pada Taraf $5 \%$

Pada perlakuan dengan pemberian pupuk cair dan pupuk anorganik hasil yang paling tinggi ditunjukan oleh perlakuan $\mathrm{F}$ dengan berat $53,31 \mathrm{~g}$ bobot gabah kering panen pertanaman. Hal ini disebabkan karena unsur hara yang tersedia belum sepenuhnya dapat diserap oleh tanaman, sehingga hara yang terkandung dari pupuk cair dan pupuk anorganik $\mathrm{N}, \mathrm{P}, \mathrm{K}$ belum berperan penuh dalam proses pembentukan bulir. Menurut Tajudin, dkk (2016) pupuk majemuk NPK mempunyai peranan dalam pembentukan protein dan karbohidrat pada gabah padi. Hal serupa juga disampaikan oleh Qiblatah dan Astuti (2016) salah satu faktor penunjang pertumbuhan dan produksi tanaman adalah unsur hara ketersediaan hara yang cukup akan menunjang pertumbuhan yang lebih baik.

\section{Kesimpulan}

Berdasarkan hasil analisis dan pembahasan pada penelitian ini, maka dapat diambil beberapa kesimpulan sebagai berikut:

1. Pemberian pupuk organik cair plus silika dengan kombinasi pupuk $\mathrm{N}, \mathrm{P}$ dan $\mathrm{K}$ Memberikan pengaruh yang nyata terhadap tinggi tanaman dan jumlah anakan pada 8 MST namun pada gabah kering panen tidak terjadi pengaruh yang nyata.

2. Pemberian pupuk organik cair plus silika dengan kombinasi pupuk $\mathrm{N}, \mathrm{P}$ dan $\mathrm{K}$ meningkatkan tinggi pada 8 MST dengan perlakuan tertinggi $64,00 \mathrm{~cm}$ dan jumlah anakan terbanyak 68,67 sedangkan gabah kering panen terbanyak seberat 53,31 g/ tanaman.

\section{Ucapan Terimakasih}

Ucapan terima kasih kami disampaikan kepada semua pihak yang telah memberikan bantuan dalam penelitian dan penulisan karya tulis ini khususnya Tim Departemen Ilmu Tanah dan Sumberdaya Lahan Fakultas Pertanian Universitas Padjadjaran.

\section{Daftar Pustaka}

Amrullah. Didy, Sopandie. Sugianta. Ahmad Junaedi. 2014. Peningkatan Produktivitas Tanaman Padi (Oryza sativa L) melalui Pemberian Nano Silika. PANGAN, Vol. 23 No. 1 Maret 2014 : 17 - 32. Bogor.

Badan Pusat Statistik. (2020). Luas Panen dan Produksi Padi Di Indonesia 2020. Badan Pusat Statistik. Jakarta

Balai Besar Penelitian dan Pengembangan Sumberdaya Lahan Pertanian Badan Penelitian dan Pengembangan Pertanian (BBSDLP). 2020. Inovasi Peningkatan Potensi Sumberdaya Lahan. Balai Besar Penelitian dan Pengembangan Sumberdaya Lahan Pertanian Badan Penelitian dan Pengembangan Pertanian. Bogor

Casman, K.G., S. Peng, and A. Dobermann. 1997. Nutritional physiology of the rice plants and productivity declined of irrigated rice systems in the tropics. Soil Sci. Plant Nutr., 43: 11011106.

E Tadjudin, Alfandi dan Yafenka, S. E. D. 2016. Pengaruh Pupuk Pelengkap Cair, Pupuk Urea Dan NPK Terhadap Pertumbuhan Dan Hasil Tanaman Padi (Oryza sativa L.) Varietas Ciherang. Agroswagati. Vol 4, No 1 (2016).

Ginanjar, R. R, Ma'ruf, A, Mulyadi, A. H. 2014. Ekstraksi Silika Dari Abu Sekam Padi Menggunakan Pelarut $\mathrm{NaOH}$. Prosiding Seminar Nasional Hasil - Hasil Penelitian dan Pengabdian LPPM UMP 2014

Hadisuwito, S. 2007. Membuat Pupuk Kompos Cair. Penerbit Agromedia Pustaka. Jakarta.

Irianto, G. 2010. Pemupukan Berimbang Saja Tidak Cukup. Sinar Tani. 3345: 7.

Isnawan, H. B dan Utama, N. A. 2015. Pemakaian Pupuk Organik Cair Sebagai Dekomposer dan Sumber Hara Tanaman Padi (Oriza sativa L.). Planta Tropika Journal of Agro Science Vol 3 No 2.

Masfufah, A. 2012. Pengaruh Pemberian Pupuk Hayati (Biofertilizer) pada Berbagai Dosis Pupuk dan 
Media tanam yang Berbeda Terhadap Pertumbuhan dan Produktifitas Tanaman Tomat (Lycopersicon esculentum) pada Polybag. Skripsi. Universitas Airlangga. Surabaya.

Pusat Penelitian Tanah dan Agroklimat (Puslittanak). 2006. Tanah-Tanah Masam di Indonesia, Inceptisol. Bogor.

Qiblatah, M dan Astuti, P. 2016. Pertumbuhan dan Hasil Tanaman Bawang Daun (Allium fistulosum L) Pada Pemotongan Bibit Anakan dan Pemmberian Pupuk Kandang Sapi dengan Sistem Vermikultur. J. Agrivigor. 2(XV): 249258

Rosmarkam, A., Yuwono, N.W. 2002. Ilmu Kesuburan Tanah. Kanisius, Yogyakarta.

Santoso, M. B. 2014. Budidaya Padi Ratun. Balai Besar Pelatihan Pertanian. Binuang.

Sitompul SM, Guritno B. 1995. Analisis Pertumbuhan Tanaman. Yogyakarta. Gadjah Mada University Press.

Sugiyanta. 2007. Peran Jerami dan Pupuk Hijau terhadap Efisiensi dan Kecukupan Hara Lima Varietas Padi Sawah. Disertasi. Institut Pertanian Bogor. 